\title{
Fertilization effects of organic waste resources and bottom wood ash: results from a pot experiment
}

\author{
Eva Brod ${ }^{1,2}$, Trond Knapp Haraldsen ${ }^{1}$ and Tor Arvid Breland ${ }^{2}$ \\ ${ }^{1}$ Bioforsk - Norwegian Institute for Agricultural and Environmental Research, Fredrik A. Dahls vei 20, 1432, Ås, Norway \\ ${ }^{2}$ Norwegian University of Life Sciences, Department of Plant and Environmental Sciences, P.O. Box 5003, 1432, Ås, Norway \\ e-mail: eva.brod@bioforsk.no
}

\begin{abstract}
A pot experiment was conducted to study the fertilization effects of four $\mathrm{N}$ - and P-rich organic waste resources alone and in combination with K-rich bottom wood ash at two application rates $\left(150 \mathrm{~kg} \mathrm{~N} \mathrm{ha}^{-1}+120 \mathrm{~kg} \mathrm{~K} \mathrm{ha}^{-1}, 300 \mathrm{~kg} \mathrm{~N}\right.$ $\mathrm{ha}^{-1}+240 \mathrm{~kg} \mathrm{~K} \mathrm{ha}^{-1}$ ). Plant-available $\mathrm{N}$ was the growth-limiting factor. $48-73 \%$ of $\mathrm{N}$ applied with meat and bone meal (MBM) and composted fish sludge (CFS) was taken up in aboveground biomass, resulting in mineral fertilizer equivalents (MFE\%) of 53-81\% for N uptake and $61-104 \%$ for yield. MFE\% of MBM and CFS decreased for increasing application rates. Two industrial composts had weak $\mathrm{N}$ fertilization effects and are to be considered as soil conditioners rather than fertilizers. Possible P and $K$ fertilization effects of waste resources were masked by the soil's ability to supply plant-available $\mathrm{P}$ and $\mathrm{K}$, but effects on plant-available $\mathrm{P}$ and $\mathrm{K}$ contents in soil suggest that the waste resources may have positive effects under more nutrient-deficient conditions.
\end{abstract}

Key words: meat and bone meal, fish sludge, compost, nitrogen use efficiency, mineral fertilizer equivalent

\section{Introduction}

Today's agriculture relies on the application of mineral fertilizers to return plant nutrients to agricultural land. However, global resources of fossil fuel and phosphate rock, raw material for the production of mineral fertilizers, are limited. According to current calculations, economically exploitable P will be exhausted within $50-100$ (Cordell et al. 2009) to 300-400 years (van Kauwenbergh 2010), and several investigations suggest that we might already have passed peak oil. In order to ensure food security in the future, we will have to reduce our dependence on mineral fertilizers and to replace linear nutrient flows by nutrient cycles.

Returning waste to agricultural land by the application of waste-based fertilizer products is a systemic approach to meeting the challenging task of future food supply. There are many derivatives from the food industry as well as waste products from industry and bioenergy plants that are considered as waste despite considerable contents of valuable plant nutrients. The potential of these by-products as fertilizers in agriculture is still largely unexploited.

Meat and bone meal (MBM) is a by-product from industrial slaughtering operations with considerable amounts of $\mathrm{N}(\sim 8 \%), \mathrm{P}(\sim 5 \%)$ and $\mathrm{Ca}(\sim 10 \%)$ (Jeng et al. 2006), making it interesting as fertilizer to agricultural crops. Each year, Norwegian slaughterhouses produce $30000 \mathrm{Mg}$ of low-risk category $3 \mathrm{MBM}$, containing about $2400 \mathrm{Mg} N$ and $1500 \mathrm{Mg} P$ (Haraldsen et al. 2011b). Assuming N and P fertilization effects of respectively $80 \%$ and $50 \%$ (Jeng et al. 2004, 2006), Norwegian MBM has the potential to compensate for $1900 \mathrm{Mg} \mathrm{N}$ and $750 \mathrm{Mg}$ P, commensurating 2\% and $10 \%$ of $\mathrm{N}$ and $\mathrm{P}$ that was applied to Norwegian agricultural land with artificial fertilizers in 2010 (SSB 2011).

Previous studies have shown that MBM is a predictable organic $N$ fertilizer with similar fertilization effects as mineral fertilizers (Salomonsson et al. 1994, 1995, Jeng et al. 2004, 2006, Chen et al. 2011), and that it has a positive effects on the baking performance of wheat (Triticum aestivum L.), as well as on common quality parameters in barley (Hordeum vulgare) and oat (Avena sativa) (Fredriksson et al. 1997, 1998, Chen et al. 2011). Phosphorus in MBM is partly present as organic $P$ in the meat fraction, which can easily be taken up by the plants, but the the largest amount is present as apatite in the bone fraction, requiring $\mathrm{H}^{+}$to become available to plants and making the $\mathrm{P}$ fertilization effect of MBM dependent on soil pH (Jeng et al. 2006, Ylivainio et al. 2008). Due to low N:P ratios $(<2-3$, Jeng et al. 2004, 2006, Ylivainio et al. 2008, Jeng and Vagstad 2009), it has previously been recommended that MBM fertilizer rates should be adjusted to the plants' $\mathrm{P}$ demands and to the long term $\mathrm{P}$ fertilization effect of the material, rather than to $\mathrm{N}$ contents (Jeng et al. 2006). 
Fish sludge is the accumulation of $\mathrm{N}$ - and P-rich faeces and feed residues on the ground of hatcheries and fish farms, which is today commonly discharged directly into the sea (Norwegian Ministry of Fisheries and Coastal 2008). Based on the number of Norwegian hatcheries for salmon and trout and their production volume we estimated that there were collected around $40000-50000 \mathrm{Mg}$ of fish sludge in 2010 . With a dry matter (DM) content of $10 \%$ and respectively $4-5 \% \mathrm{~N}$ and $2-3 \% \mathrm{P}$, Norwegian fish sludge contains $200-250 \mathrm{Mg} \mathrm{N}$ and $80-150 \mathrm{Mg}$. According to previous studies on fertilization effects both untreated and anaerobically treated fish sludge have the potential to result in larger biomass production and $\mathrm{N}$ and $\mathrm{P}$ uptake in crops than conventional animal manure (Gebauer and Eikebrokk 2006, Uhlig and Haugland 2007). Fish sludge from freshwater hatcheries is better suited as fertilizer than fish sludge originating from seawater fish farms, which can result in sodium (Na) uptake by the crops (Teuber et al. 2005). Treating fish sludge in a composting reactor developed by the company Global Enviro AS produces material that is in its consistency and composition very similar to MBM, and studies of Haraldsen and Krogstad (2011) let assume that fertilization effects of MBM and composted fish sludge (CFS) are comparable.

Biomass ashes, residues from thermal combustion activities, are potential $\mathrm{Ca}, \mathrm{P}, \mathrm{K}$ and $\mathrm{Mg}$ fertilizers, provided that their heavy metal contents are low (Mozaffari et al. 2002, Haraldsen et al. 2011b, Schiemenz et al. 2011). Still, biomass ashes have so far mainly been considered as liming products (Knapp and Insam 2011). Narrow Ca:K ratios $\left(<3\right.$ or less) and high $\mathrm{K}$ contents $\left(>6 \mathrm{~g}(100 \mathrm{~g})^{-1} \mathrm{DM}\right)$ are the requirements to ashes when used as alternative fertilizer products in order to keep their neutralizing effect in accordance with annual acidification of agricultural soils (Haraldsen et al. 2012). There are large variations in terms of quality of biomass ashes produced by Norwegian bioenergy plants and so far there is a lack of knowledge about available material of a quality fulfilling the governmental, regulative (Norwegian Ministry of Agriculture 2003) and agronomic requirements.

There are several challenges, which prevent farmers from applying by-products from food-industry and other industrial waste products to agricultural land. Some of the major drawbacks associated with the re-use of waste in agriculture are minimum requirements according to material quality (Norwegian Ministry of Agriculture 2003, §10), energy- and cost-intensive transport of products with low dry matter contents, as well as the challenge of even application of bulky or dusty waste. Moreover, actual fertilization and liming effects of waste products are largely unknown, and NPK ratios in waste material are usually unbalanced in comparison to the plants' needs (Haraldsen and Krogstad 2011, Haraldsen et al. 2011b). Combining various waste resources potentially overcomes the challenge of unbalanced NPK ratios in waste material.

Several studies have already tested the concept of recycled NPK fertilizer based on waste resources and results have been promising. Haraldsen et al. (2011b) found in a pot experiment, where combined waste resources were applied to spring cereals, that fertilization with MBM and bottom wood ash (BWA) can result in significantly larger yields than fertilization with MBM alone, and in yields as large as after fertilization with mineral compound fertilizer (Haraldsen et al. 2011b). Haraldsen and Krogstad (2011) combined various N-rich waste resources with BWA in a two-year pot experiment with spring cereals as experimental crops and suggested that BWA has potential $\mathrm{P}$ and $\mathrm{K}$ fertilization effects if $\mathrm{N}$ is in sufficient supply. Pradhan et al. (2010) studied the fertilization effect of human urine combined with wood ash during a field experiment on red beet (Beta vulgaris) and concluded that the waste-based fertilizer combination can increase plant biomass production compared to mineral compound fertilizer. Kuba et al. (2008) found that addition of wood ashes to organic waste can improve compost quality and nutrient balances in the end-product. Still, more research has to be done on the fertilization effects of specific waste resources and their combinations to improve the utilisation of containing nutrients, and to re-close nutrient cycles.

The intention of the present study was to contribute to the development of waste-based compound fertilizer products by investigating (i) N use efficiency and (ii) P and K fertilization effects of various waste resources. Since $\mathrm{N}$ turned out to be the growth-limiting factor, in the present paper we focus on $\mathrm{N}$ fertilization effects of $\mathrm{N}$-rich organic waste resources included in the experiment. Fertilization effects were determined by aboveground biomass production and nutrient uptake of Italian ryegrass (Lolium multiflorum var. italicum) in response to fertilizer application and compared with the effects of mineral compound fertilizer. 


\section{Materials and methods}

\section{Waste resources}

Waste resources included in the experiment all originated from industrialized food production or other industry activities and are briefly described in Table 1.

Table 1. Description of waste resources.

\begin{tabular}{llll}
\hline Waste resource & Abbreviation & Nutrients & Description \\
\hline Bottom wood ash & BWA & $\mathrm{K}$ & $\begin{array}{l}\text { Biomass ash originating from a grate fired boiler system of the company } \\
\text { Akershus Energi AS, which is located in Årnes }\left(63^{\circ} 96^{\prime} \mathrm{N}, 10^{\circ} 23^{\prime} \mathrm{E}\right), \mathrm{Norway}^{\prime}\end{array}$ \\
& & $\begin{array}{l}\text { Parent material was timber unfeasible for industrial use and residues from the } \\
\text { local mill. Both sources were clean of or had a low contents of heavy metals. }\end{array}$
\end{tabular}

$\begin{array}{lll}\begin{array}{l}\text { Meat and bone } \\ \text { meal }\end{array} & \text { MBM } & \text { N and P } \\ \begin{array}{l}\text { Composted fish } \\ \text { sludge }\end{array} & \text { CFS } & \text { N and P }\end{array}$

Stabilized, sanitized and pelletized meat and bone meal originating from the



Parent material was a mixture of feed residues and excrements from salmon hatchery of the company Åsen settefisk AS $\left(63^{\circ} 61^{\prime} \mathrm{N}, 11^{\circ} 05^{\prime} \mathrm{E}\right)$ in Trøndelag, Norway. After dewatering of the sludge using mechanical filters, the material was composted for $18 \mathrm{~h}$ in a reactor developed by the company Global Enviro AS.

Industrial compost. Parent material was based on an effluent containing polymers of urea, melamine and formaldehyde from the international company Dynea ASA, which is located in Lillestrøm $\left(59^{\circ} 96^{\prime} \mathrm{N}, 11^{\circ} 05^{\prime} \mathrm{E}\right)$, Norway. The effluent was cleaned through a microbial filter. The $\mathrm{N}$-rich sediment including microbial biomass of the filter was mixed with wood chips before the material was composted in windrows outdoors.

Acid Dynea compost Dynea $2004 \quad$ N Industrial compost with the same parent material as Dynea 2009. During storage polymers of formaldehyde break down to formic acid and lower the $\mathrm{pH}$ to around 3.5.

Samples of each of the waste resources were analysed before application. $\mathrm{pH}$ was determined according to NS 4720 (1979) or NS-EN 13037 (2000). The total contents of P and $\mathrm{K}$ as well as of trace elements (Cd, $\mathrm{Cr}, \mathrm{Cu}, \mathrm{Hg}, \mathrm{Ni}$, $\mathrm{Pb}, \mathrm{Zn}$ ) were determined after dissolution with nitric acid (7 $\mathrm{M} \mathrm{HNO}_{3}$ ) according to NS 4770 (1994) by simultaneous ICP-AES according to NS EN ISO 11885 (2009). Total N contents were determined by the modified Kjeldahl method (EN 13654-1 2001). $\mathrm{NO}_{2}-$ and $\mathrm{NO}_{3}-\mathrm{N}$ and $\mathrm{NH}_{4}-\mathrm{N}$ were determined after extraction with $2 \mathrm{M} \mathrm{KCl}$ (Henriksen and Selmer-Olsen 1970, Selmer-Olsen 1971) by a Konelab Aqua 60 analyser. To analyse the content of total organic carbon (TOC), the material was first washed with a $2 \mathrm{M} \mathrm{HCl}$ solution to remove any inorganic carbon. Then a crushed sample was burned at $925^{\circ} \mathrm{C}$ using a Perkin Elmer $2400 \mathrm{CHN}$ analyser. Readily available P-AL, $\mathrm{K}-\mathrm{AL}, \mathrm{Mg}-\mathrm{AL}$ and $\mathrm{Ca}-\mathrm{AL}$ were determined on ICP-AES after extraction with a solution composed of $0.4 \mathrm{M}$ acetic acid and $0.1 \mathrm{M}$ ammonium lactate $(\mathrm{pH} 3.75)$ in a solid-to-solution ratio of 1:20 (w/v) (Egnér et al. 1960). Table 2 summarizes the chemical properties of the waste resources that were applied as fertilizer in the experiment.

MBM and CFS had high contents of $N$ and $P . N$ : $P$ ratios were 2 and 4, respectively. BWA was due to its high $K$ content and solubility of the nutrient in ashes considered as potential $\mathrm{K}$ fertilizer. BWA also contained some P but plantavailability was assumed to be low according to P-AL analysis. Dynea compost is an N-rich industrial by-product of the industry business Dynea ASA in Lillestrøm, Norway. Even if the annual production is minor, Dynea compost is a valuable local resource and studies on the material were, therefore, included in the experiment. 
Table 2. Chemical characteristics of waste resources. See Table 1 for explanation of the abbreviations of the waste resources.

\begin{tabular}{|c|c|c|c|c|c|}
\hline Parameter, unit & BWA & MBM & CFS & Dynea 2009 & Dynea 2004 \\
\hline $\mathrm{pH}$ & 12.0 & 6.5 & 5.7 & 7.3 & 3.5 \\
\hline $\mathrm{DM}, \mathrm{g}(100 \mathrm{~g})^{-1}$ & 100 & 98 & 86 & 29 & 43 \\
\hline Loss on ignition, $\mathrm{g}(100 \mathrm{~g})^{-1} \mathrm{DM}$ & 0.23 & 71 & 88 & 66 & 63 \\
\hline Total N, g (100g) $)^{-1} \mathrm{DM}$ & 0.1 & 9.0 & 6.9 & 7.3 & 7.8 \\
\hline $\mathrm{C}: \mathrm{N}$ ratio & 1 & 5 & 7 & 5 & 5 \\
\hline $\mathrm{NH}_{4}-\mathrm{N}, \mathrm{g}(100 \mathrm{~g})^{-1} \mathrm{DM}$ & 0.00046 & 0.03100 & 0.25850 & 0.00887 & 0.06410 \\
\hline $\mathrm{NO}_{2}-$ and $\mathrm{NO}_{3}-\mathrm{N}, \mathrm{g}(100 \mathrm{~g})^{-1} \mathrm{DM}$ & 0.00036 & 0.00028 & 0.00019 & 0.08400 & 0.17960 \\
\hline $\mathrm{N}_{\min }(\%$ of total $\mathrm{N})$ & 0.81 & 0.35 & 3.75 & 1.27 & 3.12 \\
\hline Total P, g (100g)-1 DM & 1.7 & 4.5 & 1.7 & 0.2 & 0.3 \\
\hline P-AL, g (100g) $)^{-1} \mathrm{DM}$ & 0.19 & 2.00 & 1.60 & 0.09 & 0.06 \\
\hline $\mathrm{N}: \mathrm{P}$ ratio & 0.06 & 2 & 4 & 37 & 31 \\
\hline $\mathrm{N}: \mathrm{P}-\mathrm{AL}$ ratio & 1 & 5 & 4 & 84 & 130 \\
\hline Total K, g (100g) $)^{-1} \mathrm{DM}$ & 7.7 & n.d. & 0.15 & n.d. & n.d. \\
\hline K-AL, g $(100 \mathrm{~g})^{-1} \mathrm{DM}$ & 6.4 & 0.3 & 0.3 & 0.1 & 0.0 \\
\hline Mg-AL, g (100g) $)^{-1} \mathrm{DM}$ & 1.5 & 0.1 & 0.3 & 0.1 & 0.0 \\
\hline Ca-AL, g (100g)-1 DM & 8.6 & 4.2 & 2.8 & 0.8 & 0.0 \\
\hline
\end{tabular}

$\mathrm{DM}=$ dry matter, $\mathrm{N}_{\min }=$ ammonium- $\mathrm{N}$ and nitrate- $\mathrm{N}, \mathrm{AL}=$ extraction with $0.4 \mathrm{M}$ acetic acid and $0.1 \mathrm{M}$ ammonium lactate, $\mathrm{n} . \mathrm{d} .=$ not determined.

All of the waste resources fulfilled the Norwegian requirements for waste-based fertilizer products. For content of heavy metals in the waste resources see Table 3. MBM was in quality class 0 according the Norwegian regulations considering the content of heavy metals in the material. Therefore, there are no restrictions regarding the amount of MBM that could be applied to agricultural land other than the plants' demands, and that it should not be applied on areas for grazing and production of grass for feeding of production animals unless it is blended with a mixing component, according to the EU by-product ordinance $1774 / 2002$. BWA and CFS were in quality class I, their use on agricultural land would therefore be restricted to $40 \mathrm{Mg} \mathrm{DM} \mathrm{ha}^{-1}$ and $10 \mathrm{yr}^{-1}$. Both Dynea 2009 and Dynea 2004 were in quality class II. Therefore, their use on agricultural land would be restricted to $20 \mathrm{Mg} \mathrm{DM} \mathrm{ha}^{-1}$ and $10 \mathrm{yr}^{-1}$ (Norwegian Ministry of Agriculture 2003, $\S 10$ and $\left.\S 27\right)$. According to the current legislation on organic farming in Norway (Mattilsynet 2009), the use of MBM and untreated BWA is also allowed on organic agricultural fields. The parent material of CFS is in its consistency and composition similar to animal manure and can, therefore, be defined as animal manure of fish. The content of heavy metals in CFS was at the same level as Norwegian animal manure from various types of animals (Paulsrud et al. 1997).

Table 3. Contents of heavy metals ( $\mathrm{mg} \mathrm{kg}^{-1} \mathrm{dry}$ matter) in waste resources. See Table 1 for explanation of the abbreviations of the waste resources.

\begin{tabular}{llllll}
\hline Parameter & BWA & MBM & CFS & Dynea 2009 & Dynea 2004 \\
\hline $\mathrm{Cd}$ & 0.60 & 0.02 & 0.40 & 0.21 & 0.27 \\
$\mathrm{Cr}$ & 15.00 & 1.60 & 1.70 & 15.00 & 16.00 \\
$\mathrm{Cu}$ & 75.00 & 8.70 & 11.00 & 42.00 & 59.00 \\
$\mathrm{Hg}$ & 0.00 & 0.01 & 0.01 & 0.18 & 0.73 \\
$\mathrm{Ni}$ & 16.00 & 1.80 & 0.53 & 32.00 & 22.00 \\
$\mathrm{~Pb}$ & 7.80 & 1.10 & 0.35 & 33.00 & 31.00 \\
$\mathrm{Zn}$ & 200.00 & 99.00 & 290.00 & 150.00 & 84.00 \\
\hline
\end{tabular}


The experimental soil was a sandy loam with large fractions of gravel and organic matter with origin in Kise $\left(60^{\circ} 78^{\prime} \mathrm{N}, 10^{\circ} 81^{\prime} \mathrm{E}\right)$ in the municipality Ringsaker in Norway, where rocks are calciferous dolomites and sediments are morainic soils (NGU 2011). Table 4 is an overview over the distribution of the size of soil particles, which was determined according to Elonen (1971).

Table 4. Size of soil particles in the experimental soil.

\begin{tabular}{llllllll}
\hline Unit & Coarse sand & Medium sand & Fine sand & Coarse silt & Medium silt & Fine silt \\
\hline $\mathrm{mm}$ & $2-0.6$ & $0.6-0.2$ & $0.2-0.06$ & $0.06-0.02$ & $0.02-0.006$ & $0.006-0.002$ \\
$\%$ & 21.4 & 25.1 & 11.0 & 9.4 & 9.4 & 6.6 & 17.1 \\
\hline
\end{tabular}

Table 5 describes the chemical characteristics of the soil used in the experiment, which was taken from an experimental field with organic production in 2009. Analyses were conducted in 2009. TOC, P-AL, K-AL, Mg-AL and Ca-AL were determined by the methods as described for the waste resources. $\mathrm{K}-\mathrm{HNO}_{3}$, an estimate for exchangeable and non-exchangeable $\mathrm{K}$ reserves in the soil, was determined after boiling the soil in a $1 \mathrm{HNO}_{3}$ solution (Pratt 1965). $\mathrm{pH}$ was determined in a soil water suspension of 1:2.5 (v/v). Contents of readily available P-AL were low, contents of readily available $\mathrm{K}-\mathrm{AL}$ were intermediate and $\mathrm{K}$ reserves measured as acid-soluble $\mathrm{K}-\mathrm{HNO}_{3}$ were low (Bioforsk 2003). Low nutrient contents in the soil were supposed to enable the evaluation of NPK fertilization effects of the waste resources. Due to the soil's origin in calciferous dolomite rocks, it contained considerable amounts of $\mathrm{Mg}-\mathrm{AL}$ and large amounts of Ca-AL (Landbrukets analysesenter s.a.). The waste resources were not assessed regarding their contents of $\mathrm{Mg}$ and $\mathrm{Ca}$, and adequate amounts in the soil were, therefore, desirable to prevent deficiency of $\mathrm{Mg}$ and $\mathrm{Ca}$ in the plants.

Table 5. Chemical characteristics of the experimental soil at the beginning of the experiment (measured in 2009).

\begin{tabular}{lllllllll}
\hline $\mathrm{pH}$ & $\mathrm{TOC}$ & Total N & $\mathrm{C}: \mathrm{N}$ & $\mathrm{P}-\mathrm{AL}$ & $\mathrm{K}-\mathrm{AL}$ & $\mathrm{K}-\mathrm{HNO}_{3}$ & $\mathrm{Mg}-\mathrm{AL}$ & $\mathrm{Ca}-\mathrm{AL}$ \\
& $\mathrm{g}(100 \mathrm{~g})^{-1}$ & $\mathrm{~g}(100 \mathrm{~g})^{-1}$ & & $\mathrm{mg}(100 \mathrm{~g})^{-1}$ & $\mathrm{mg}(100 \mathrm{~g})^{-1}$ & $\mathrm{mg}(100 \mathrm{~g})^{-1}$ & $\mathrm{mg}(100 \mathrm{~g})^{-1}$ & $\mathrm{mg}(100 \mathrm{~g})^{-1}$ \\
\hline $6.4-6.5$ & $3.1-3.3$ & $0.27-0.31$ & $11.3-11.8$ & $2.5-3.0$ & $8.2-8.7$ & $34-38$ & $15-17$ & $284-304$ \\
\hline
\end{tabular}

$\mathrm{TOC}=$ total organic carbon, $\mathrm{AL}=$ extraction with ammonium lactate, $\mathrm{HNO}_{3}=$ extraction with nitric acid.

In 2009, 2/3 of the soil was used for a pot experiment with Chinese cabbage (Brassica rapa), where different liming strategies were tested, and in 2010 spring wheat (Triticum aestivum) was grown to test the fertilization effect of digestate from biogas plants. In both cases, fertilization was adapted to the plants' needs and a decrease or increase of nutrient contents in the soil was, therefore, not expected. About $1 / 3$ of the soil had been stored under outdoor conditions for the last three years, when we mixed all of the soil thoroughly during set-up of the experiment. Possible influences of previous activities were, therefore, evenly distributed on all experimental treatments. The soil was sieved at a mesh width of $4 \mathrm{~mm}$ to sort out the gravel before filling of experimental pots. After the experiment had finished, soil samples from all of treatments were taken $(0-20 \mathrm{~cm}) . \mathrm{pH}, \mathrm{Ca}-\mathrm{AL}, \mathrm{K}-\mathrm{AL}, \mathrm{Mg}-\mathrm{AL}, \mathrm{Na}-$ $\mathrm{AL}, \mathrm{P}-\mathrm{AL}, \mathrm{NO}_{2}$ - and $\mathrm{NO}_{3}-\mathrm{N}$ and $\mathrm{NH}_{4}-\mathrm{N}$ were determined as described.

\section{Experimental design}

The experiment was conducted outdoors under a transparent, synthetic roof in Ås, Norway $\left(59^{\circ} 39^{\prime} \mathrm{N}, 10^{\circ} 45^{\prime} \mathrm{E}\right)$. Kick/Brauckmann pots $(7.5 \mathrm{I}$ with a top diameter of $21.5 \mathrm{~cm}$ ) were randomized side by side on a table where the plants were protected from precipitation but otherwise exposed to daylight and outdoor climate. Due to wind protection on the north and east side of the roof, average temperature was somewhat higher than data for the growing season, which is presented in Table 6. 
Table 6. Average temperature $\left({ }^{\circ} \mathrm{C}\right)$ for each month compared to the standard reference period (Lippestad 2011).

\begin{tabular}{lll} 
& \multicolumn{2}{l}{ Temperature $\left({ }^{\circ} \mathrm{C}\right)$} \\
\hline May & 2011 & Reference period ${ }^{\mathrm{a}}$ \\
June & 10.5 & 10.3 \\
July & 15.0 & 14.8 \\
August & 17.0 & 16.1 \\
September & 15.3 & 14.9 \\
\hline${ }^{a}$ Monthly temperature average in the period 1961-1990.
\end{tabular}

a Monthly temperature average in the period 1961-1990.

The plants were irrigated three times a week. Each pot was watered up and kept at a water level of $0.25-0.35 \mathrm{~m}^{3}$ $\mathrm{m}^{-3}$, which was estimated to represent a water potential between -10 and $-100 \mathrm{kPa}$ in the experimental soil. To measure the soil water content a HH2 moisture meter with a Delta-T Devices soil moisture sensor SM 200 was used.

The experimental crop was Italian ryegrass (Lolium multiflorum var. italicum cv. 'Macho'), which commonly clearly responds to fertilization (Frame 1992) being a good indicator of the amount of plant-available nutrients in soils. Hence, it was used to study mineralization rates and fertilization effects of the waste resources by uptake of nutrients in aboveground biomass. In the field, seed rates of $30-40 \mathrm{~kg} \mathrm{ha}^{-1}$ are recommended when Italian ryegrass is sown in pure stand (Lund et al. 2011). In the pot experiment a seed rate of $30 \mathrm{~kg} \mathrm{ha}^{-1}$ was chosen. This amount is equivalent to $0.11 \mathrm{~g} \mathrm{pot}^{-1}$.

The experiment was designed to supply plants with N, P and K similar to that supplied with the compound fertilizer Yara Fullgjødsel ${ }^{\circledR} 18-3-15$ (minNPK). All of the four N-rich waste resources were tested alone and in combination with K-rich BWA. Fertilizer combinations were compared with the effect of minNPK. An unfertilized treatment and only calcium nitrate $(\mathrm{minN})$ were included to study the soil's ability to supply plant nutrients. Additionally, there were reference treatments with $\min N$ in combination with BWA and BWA alone. Each treatment was tested at two application rates, calculated with respect to the amount of total $\mathrm{N}$ (Kjeldahl-N) and total $\mathrm{K}$ content (extraction with $7 \mathrm{M} \mathrm{HNO}_{3}$ ) in N-rich waste and K-rich BWA, respectively. Application rates (150 kg N ha-1 $+120 \mathrm{~kg}$ $\mathrm{K} \mathrm{ha}^{-1}$ by $300 \mathrm{~kg} \mathrm{~N} \mathrm{ha}^{-1}+240 \mathrm{~kg} \mathrm{~K} \mathrm{ha}^{-1}$ ) were chosen based on fertilizer recommendations for pastures with three cuts in Norway (Bioforsk 2003), and calculated based on the surface area of the pots. The soil depth was with 20 $\mathrm{cm}$ in accordance with the depth of cultivated topsoil. There were three replicates for each treatment. The experimental design is presented in Table 7.

Planting took place on 9 May 2011. The upper $5 \mathrm{~cm}$ of soil in the pots were removed and fertilizer was applied evenly on the soil together with the seeds. Then the upper soil layer was placed back on top. Hence, seeds were placed deeper than intended, and deeper than commonly recommended for grasses, resulting in delayed germination and reduced biomass production during the first harvest (Table 8). During the first weeks, weeds were removed to avoid interplant competition until the experimental crop was fully established. The pots did not receive any further fertilization throughout the summer.

Biomass was harvested manually with scissors at a height of $1.5 \mathrm{~cm}$ from soil surface on 21 June, 19 July, 17 August and 27 September 2011. For each pot, plant material was dried at $40{ }^{\circ} \mathrm{C}$ for one week, and dry matter production was calculated. Chemical analyses were conducted for one pooled sample per treatment. Total $\mathrm{N}$ in plant material was determined by the Dumas method (NS-EN 13654-2 2001). Total tissue concentrations of P, K, Mg, Ca and micronutrients were determined as described for the waste resources. Nutrient uptake $\left(\mathrm{kg} \mathrm{ha}^{-1}\right)$ was computed by multiplying concentration of the pooled samples by the yield of each replication. 
Table 7. Amount of waste resources applied with contents of mineral $N\left(N_{\text {min }}\right)$, total $P, P-A L$ and total $K / K-A L$ as $k g$ ha ${ }^{-1}$. See Table 1 for explanation of the abbreviations of the waste resources.

\begin{tabular}{|c|c|c|c|c|c|c|c|c|c|c|}
\hline \multirow[b]{3}{*}{ Treatment } & \multicolumn{10}{|c|}{ Application rates } \\
\hline & \multicolumn{5}{|c|}{$150 \mathrm{~kg} \mathrm{~N} \mathrm{ha}^{-1}+120 \mathrm{~kg} \mathrm{~K} \mathrm{ha}^{-1}$} & \multicolumn{5}{|c|}{300 kg N ha ${ }^{-1}+240 \mathrm{~kg} \mathrm{~K} \mathrm{ha}^{-1}$} \\
\hline & Amount & $\mathrm{N}_{\min }$ & total $\mathrm{P}$ & P-AL & $\mathrm{K} /-\mathrm{AL}^{\mathrm{a}}$ & Amount & $\mathrm{N}_{\min }$ & $\begin{array}{l}\text { total } \\
P\end{array}$ & P-AL & $\mathrm{K} /-\mathrm{AL}{ }^{\mathrm{a}}$ \\
\hline BWA & 1558 & 0 & 26 & 3 & 120 & 3117 & 0 & 53 & 6 & 240 \\
\hline $\operatorname{minNPK}$ & 852 & 150 & 22 & 22 & 124 & 1705 & 300 & 44 & 44 & 249 \\
\hline $\min N$ & 968 & 150 & 0 & 0 & 0 & 1935 & 300 & 0 & 0 & 0 \\
\hline $\min N+B W A$ & 2526 & 150 & 26 & 3 & 120 & 5052 & 300 & 53 & 6 & 240 \\
\hline MBM & 1701 & 0.5 & 75 & 33 & 5 & 3401 & 1 & 150 & 67 & 10 \\
\hline$M B M+B W A$ & 3259 & 0.5 & 101 & 36 & 125 & 6518 & 1 & 203 & 73 & 250 \\
\hline CFS & 2528 & 5.6 & 37 & 35 & 7 & 5056 & 11 & 74 & 70 & 13 \\
\hline $\mathrm{CFS}+\mathrm{BWA}$ & 4086 & 5.6 & 63 & 38 & 127 & 8172 & 11 & 127 & 75 & 253 \\
\hline Dynea 2009 & 7110 & 0.5 & 4 & 0 & 2 & 14220 & 1 & 8 & 0 & 4 \\
\hline Dynea 2009 + BWA & 8668 & 0.5 & 31 & 3 & 122 & 17337 & 1 & 61 & 6 & 244 \\
\hline Dynea 2004 & 4495 & 4.7 & 6 & 1 & 0 & 8991 & 9 & 12 & 2 & 0 \\
\hline Dynea 2004 + BWA & 6054 & 4.7 & 32 & 4 & 120 & 12107 & 9 & 65 & 8 & 240 \\
\hline
\end{tabular}

${ }^{\mathrm{a}} \mathrm{K}$ in BWA was calculated based on total $\mathrm{K} . \mathrm{K}$ in other material is based on $\mathrm{K}-\mathrm{AL}$. AL = extraction with $0.4 \mathrm{M}$ acetic acid and $0.1 \mathrm{M}$ ammonium lactate.

\section{Data analysis}

Nitrogen use efficiency (NUE\%, Salomonsson et al. 1994, 1995, Jeng et al. 2004) was calculated as follows:

$\operatorname{NUE}(\%)=\frac{100 \times\left[\mathrm{N}_{\text {up }}-\mathrm{N}_{\text {up }}(\mathrm{c})\right]}{\mathrm{N}_{\text {applied }}}$

where

NUE $=\mathrm{N}$ use efficiency

$\mathrm{N}_{\text {up }}=\mathrm{N}$ in aboveground biomass as sum of all four harvests $\left(\mathrm{kg} \mathrm{N} \mathrm{ha}^{-1}\right)$

$\mathrm{C}=$ unfertilized control treatment

$\mathrm{N}_{\text {applied }}=$ Total $\mathrm{N}$ amount applied with fertilizer treatment

Mineral fertilizer equivalent (MFE\%, Delin 2011), which is defined as the application rate of mineral fertilizer N (kg $\mathrm{N} \mathrm{ha}^{-1}$ ) to which the fertilization effect of organic waste on yield or $\mathrm{N}$ uptake $(\mathrm{Y})$ is equivalent, expressed as percentage of total $\mathrm{N}$ applied, was calculated as follows:

$\mathrm{MFE} \%=100 \times \mathrm{X}_{1} / \mathrm{X}_{\mathrm{tot}}$

where

MFE $=$ mineral fertilizer equivalent

$\mathrm{X}_{\text {tot }}=150$ or $300 \mathrm{~kg} \mathrm{~N} \mathrm{ha}^{-1}$

$\mathrm{X}_{1}=\left(\mathrm{Y}_{1}-\mathrm{b}\right) / \mathrm{a}$

$\mathrm{Y}_{1}=$ yield or $\mathrm{N}$ uptake obtained with waste resource

$\mathrm{a}$ and $\mathrm{b}$ are slope and intercept obtained from linear regression by the minimum least squares method of yield or $\mathrm{N}$ uptake $(\mathrm{Y})$ obtained with mineral fertilizer (minNPK) on mineral $\mathrm{N}$ application rate $(\mathrm{X}=0,150$ and $300 \mathrm{~kg} \mathrm{~N}$ $\mathrm{ha}^{-1}$, respectively).

Multiple comparisons between treatments were statistically performed by one-way analysis of variance (ANOVA) including all treatments. Tukey's studentized range test was applied with a significance level of $p \leq 0.05$. The program package SAS/STAT (SAS Institute Inc. 1989) was used for the statistical analysis. 


\section{Results \\ Effects of fertilizer treatments on biomass production}

The highest fertilizer rates of minNPK and $\operatorname{minN}$ treatments resulted in the largest total yields (Table 8). The regression of yield $(\mathrm{Y})$ on mineral $\mathrm{N}$ application rate $(\mathrm{X})$ gave the following response function: $\mathrm{Y}=24.46 \mathrm{X}+2157.95$ $\left(R^{2}=0.98\right)$.

Table 8. Mean $(\mathrm{n}=3)$ biomass production $\left(\mathrm{kg} \mathrm{ha}^{-1}\right)$ as influenced by the fertilizer treatments. See Table 1 for explanation of the abbreviations of the waste resources.

\begin{tabular}{|c|c|c|c|c|c|c|}
\hline Treatment & $\begin{array}{l}\text { Amount } \\
\text { applied }\end{array}$ & $1^{\text {st }}$ harvest & $2^{\text {nd }}$ harvest & $3^{\text {rd }}$ harvest & $4^{\text {th }}$ harvest & Total \\
\hline Control & 0 & 489 & 877 & 445 & 146 & 1958 \\
\hline \multirow[t]{2}{*}{ BWA } & 150 & 593 & 1068 & 552 & 326 & 2539 \\
\hline & 300 & 451 & 1387 & 628 & 329 & 2795 \\
\hline \multirow[t]{2}{*}{$\operatorname{minNPK}$} & 150 & 669 & 3355 & 1722 & 482 & 6228 \\
\hline & 300 & 716 & 4796 & 2911 & 872 & 9295 \\
\hline \multirow[t]{2}{*}{$\min N$} & 150 & 401 & 2556 & 2407 & 673 & 6038 \\
\hline & 300 & 268 & 2370 & 4403 & 1839 & 8879 \\
\hline \multirow[t]{2}{*}{$\min N+B W A$} & 150 & 490 & 3095 & 2271 & 431 & 6287 \\
\hline & 300 & 231 & 2073 & 3960 & 1994 & 8258 \\
\hline \multirow[t]{2}{*}{ MBM } & 150 & 549 & 2882 & 1353 & 621 & 5405 \\
\hline & 300 & 354 & 3062 & 2570 & 837 & 6823 \\
\hline \multirow[t]{2}{*}{$M B M+B W A$} & 150 & 558 & 3178 & 1510 & 720 & 5966 \\
\hline & 300 & 544 & 3552 & 1886 & 665 & 6647 \\
\hline \multirow[t]{2}{*}{ CFS } & 150 & 717 & 2795 & 1146 & 680 & 5338 \\
\hline & 300 & 713 & 3396 & 1801 & 930 & 6840 \\
\hline \multirow[t]{2}{*}{ CFS + BWA } & 150 & 713 & 2794 & 1104 & 656 & 5266 \\
\hline & 300 & 553 & 3621 & 2059 & 991 & 7224 \\
\hline \multirow[t]{2}{*}{ Dynea 2009} & 150 & 409 & 1285 & 617 & 391 & 2701 \\
\hline & 300 & 492 & 1116 & 578 & 388 & 2574 \\
\hline \multirow[t]{2}{*}{ Dynea 2009 + BWA } & 150 & 490 & 876 & 421 & 315 & 2103 \\
\hline & 300 & 381 & 1250 & 647 & 450 & 2728 \\
\hline \multirow[t]{2}{*}{ Dynea 2004} & 150 & 452 & 1789 & 733 & 445 & 3418 \\
\hline & 300 & 428 & 2096 & 1023 & 479 & 4026 \\
\hline \multirow[t]{2}{*}{ Dynea 2004 + BWA } & 150 & 441 & 1931 & 813 & 454 & 3638 \\
\hline & 300 & 320 & 2034 & 960 & 442 & 3755 \\
\hline $\mathrm{MSD}^{\mathrm{a}}, p \leq 0.05$ & & 455 & 1242 & 1076 & 555 & 1965 \\
\hline
\end{tabular}

${ }^{a} \mathrm{MSD}=$ minimum significant difference.

Application of MBM and CFS resulted in similar biomass production. All in all, total yields were smaller after MBM and CFS fertilization than after mineral fertilizer treatments of the same $\mathrm{N}$ amount, but differences were only significant for the higher rates ( $300 \mathrm{~kg} \mathrm{~N} \mathrm{ha}^{-1}$ ). According to calculations of MFE\% for yield (Table 9) MBM and CFS could respectively achieve $89-104 \%$ and $85-97 \%$ of the total yield of $150 \mathrm{~kg} \mathrm{~N} \mathrm{ha}^{-1}$ minNPK and $61-64 \%$ and $64-69 \%$ after fertilization with the total yield of $300 \mathrm{~kg} \mathrm{~N} \mathrm{ha}^{-1}$ minNPK. Among Dynea compost treatments, only the effect of $300 \mathrm{~kg} \mathrm{~N} \mathrm{ha}^{-1}$ Dynea 2004 was significantly different from the unfertilized control treatment. Dynea 2009 and 2004 compensated for up to $15 \%$ and for $34-40 \%$ of the total yield after fertilization with $150 \mathrm{~kg} \mathrm{~N} \mathrm{ha}^{-1} \mathrm{minNPK}$ and for $6-8 \%$ and $22-25 \%$ of the total yield after fertilization with $300 \mathrm{~kg} \mathrm{~N} \mathrm{ha}^{-1}$ minNPK (Table 9). Dynea 2004 resulted generally in larger yields than Dynea 2009, but differences between effects of the two compost types were not significant. Application of BWA alone resulted in equally small yield as the unfertilized control reference and there was no significant effect of BWA in combination with $\operatorname{minN}$ or N-rich waste resources on biomass production in comparison to the same treatment without BWA. 
At the first harvest, yields were very small (Table 8). However, despite poor establishment there was no need of reseeding, as reduced germination was compensated by tillering. Especially minN treatments resulted in poor establishment and $300 \mathrm{~kg} \mathrm{~N} \mathrm{ha}^{-1} \mathrm{minN}+$ BWA gave the smallest yield. $150 \mathrm{~kg} \mathrm{~N} \mathrm{ha}^{-1}$ CFS without BWA and $300 \mathrm{~kg}$ $\mathrm{N}$ ha ${ }^{-1}$ minNPK resulted in the largest yields, but their effects were only significantly different from the poorly established $\operatorname{minN}+$ BWA (300 kg N ha ${ }^{-1}$ ) treatment. During the second harvest, $300 \mathrm{~kg} \mathrm{~N} \mathrm{ha}^{-1}$ minNPK treatments resulted in significantly larger biomass than all other treatments except for $300 \mathrm{~kg} \mathrm{~N} \mathrm{ha}^{-1} \mathrm{CFS}+\mathrm{BWA}$. MinN treatments of the lowest application rate $\left(150 \mathrm{~kg} \mathrm{~N} \mathrm{ha}^{-1}\right)$ resulted in biomass production at the same level as all MBM and CFS treatments, and $300 \mathrm{~kg} \mathrm{~N} \mathrm{ha}^{-1} \mathrm{minN}$ treatments tended to result in smaller yields than lower application rates $\left(150 \mathrm{~kg} \mathrm{~N} \mathrm{ha}^{-1}\right)$. At times of the third harvest, plants that had been fertilized with minN, were well developed and $300 \mathrm{~kg} \mathrm{~N} \mathrm{ha}^{-1}$ minN treatments resulted in the largest yields among all treatments. There were no significant differences between effects of minNPK, MBM and CFS treatments of the same application rate. At the fourth harvest, yields were again small in general. Biomass production after fertilization with $300 \mathrm{~kg} \mathrm{~N} \mathrm{ha}^{-1} \mathrm{minN}$ was significantly different from all other treatments (Table 8).

\section{Effects of fertilizer treatments on $\mathrm{N}$ in plant biomass and soil}

$\mathrm{N}$ uptake of unfertilized plants indicated that about $39 \mathrm{~kg} \mathrm{~N} \mathrm{ha}^{-1}$ was directly plant-available from the experimental soil. Plants utilized $86-107 \%$ of $\mathrm{N}$ applied with minNPK and minN (NUE\%, Fig. 1). After MBM and CFS fertilization, respectively, plants utilized $49-73 \%$ and $48-50 \%$ of $\mathrm{N}$ applied. After MBM and CFS fertilization, plants took up less $\mathrm{N}$ than after mineral fertilizer treatments of the same $\mathrm{N}$ amount, but differences were only significant for $300 \mathrm{~kg} \mathrm{~N} \mathrm{ha}^{-1}$ treatments. None of the Dynea compost treatments was significantly different from the unfertilized control treatment regarding N uptake in biomass. Plants took up 3-11\% of N applied with Dynea 2009 and $16-28 \%$ of $\mathrm{N}$ applied with Dynea 2004 (NUE\%, Fig. 1).

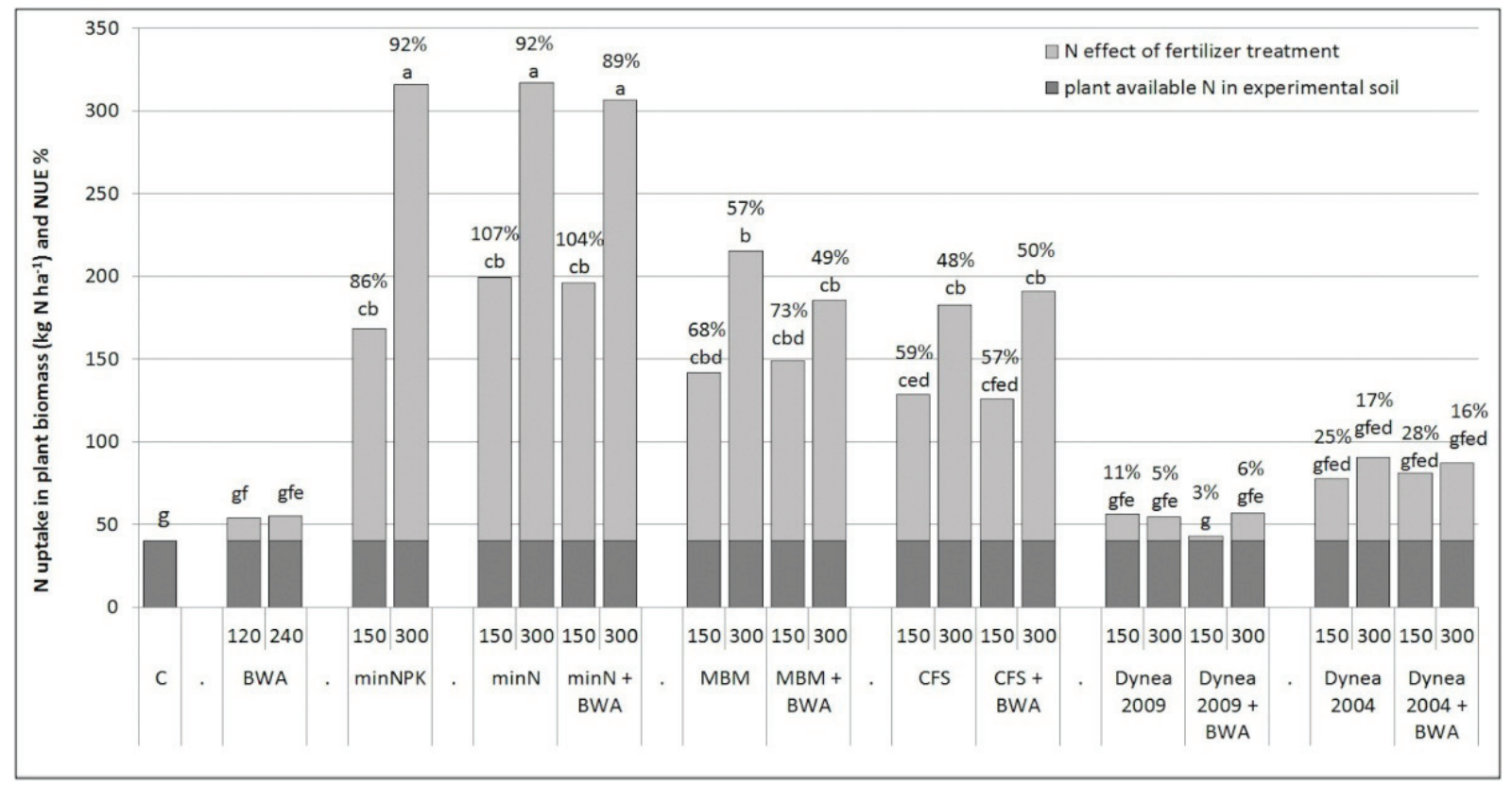

Fig. 1. Total $\mathrm{N}$ uptake in plant biomass $\left(\mathrm{kg} \mathrm{N} \mathrm{ha}^{-1}\right)$ as influenced by fertilizer treatments $\left(150 \mathrm{~kg} \mathrm{~N} \mathrm{ha}^{-1}+120 \mathrm{~kg} \mathrm{~K} \mathrm{ha}^{-1}, 300 \mathrm{~kg} \mathrm{~N} \mathrm{ha}^{-1}+240\right.$ $\mathrm{kg} \mathrm{K} \mathrm{ha}^{-1}$ ). Percentages refer to NUE (\%). Means followed by the same letter are not statistically different. See Table 1 for explanation of the abbreviations of the waste resources, $\mathrm{C}=$ unfertilized control treatment.

The regression of $\mathrm{N}$ uptake $(\mathrm{Y})$ on mineral $\mathrm{N}$ application rate $(\mathrm{X})$ gave the following response function: $\mathrm{Y}=0.92 \mathrm{X}$ $+36.21\left(R^{2}=0.98\right)$. MFE\% for $N$ uptake showed that MBM and CFS, could, respectively, compensate for $76-81 \%$ and $65-67 \%$ of $\mathrm{N}$ uptake after fertilization with $150 \mathrm{~kg} \mathrm{~N} \mathrm{ha}^{-1} \mathrm{minNPK}$, and for 54-65\% and 53-56\% after fertilization with $300 \mathrm{~kg} \mathrm{~N} \mathrm{ha}^{-1}$ minNPK. Dynea composts could compensate for 5-32\% of $\mathrm{N}$ uptake after fertilization with $150 \mathrm{~kg} \mathrm{~N} \mathrm{ha}^{-1}$ minNPK, and for 7-19\% after fertilization with $300 \mathrm{~kg} \mathrm{~N} \mathrm{ha}^{-1}$ minNPK (MFE\% for N uptake, Table 9). 
43 days after MBM and CFS fertilization (first harvest), 5-13\% of the $\mathrm{N}$ harvested during the entire experimentalperiod was present in aboveground biomass, and 71 days after MBM and CFS fertilization (second harvest) 50-67\% of the $\mathrm{N}$ harvested during the entire experimental period was present in aboveground biomass. 100 days after MBM and CFS fertilization (third harvest) $86-89 \%$ of totally harvested $\mathrm{N}$ was taken up in aboveground biomass.

Analyses of soil samples that were taken at the last day of the experiment suggested that practically all plantavailable $\mathrm{N}$ was taken up by the plants. There were no significant differences between the treatments regarding residual mineral $\mathrm{N}$ in the soil. The minimum significant difference was $0.2 \mathrm{mg}(100 \mathrm{~g})^{-1}$ soil for $\mathrm{NH}_{4}-\mathrm{N}_{\text {and }} \mathrm{NO}_{2}$ - and $\mathrm{NO}_{3}-\mathrm{N}$ measurements, respectively. Assuming soil density of $1.2 \mathrm{~g} \mathrm{~cm}^{-3}$ and soil depth of $20 \mathrm{~cm}$, there was around $10 \mathrm{~kg} \mathrm{ha}^{-1}$ of mineral $\mathrm{N}$ left in the soil on the day of the last harvest (results not shown).

Table 9. Mineral fertilizer equivalents (MFE\%) of organic waste resources for yield and N uptake. See Table 1 for explanation of the abbreviations of the waste resources.

\begin{tabular}{|c|c|c|c|c|}
\hline \multirow[b]{3}{*}{ Treatment } & \multicolumn{4}{|c|}{ Application rates } \\
\hline & \multicolumn{2}{|c|}{150 kg N ha ${ }^{-1}+120 \mathrm{~kg} \mathrm{~K} \mathrm{ha}^{-1}$} & \multicolumn{2}{|c|}{300 kg N ha ${ }^{-1}+240 \mathrm{~kg} \mathrm{~K} \mathrm{ha}^{-1}$} \\
\hline & Yield & N uptake & Yield & $\mathrm{N}$ uptake \\
\hline MBM & 89 & 76 & 64 & 65 \\
\hline$M B M+B W A$ & 104 & 81 & 61 & 54 \\
\hline CFS & 87 & 67 & 64 & 53 \\
\hline CFS + BWA & 85 & 65 & 69 & 56 \\
\hline Dynea 2009 & 15 & 14 & 6 & 7 \\
\hline Dynea 2009 + BWA & -2 & 5 & 8 & 7 \\
\hline Dynea 2004 & 34 & 30 & 25 & 19 \\
\hline Dynea 2004 + BWA & 40 & 32 & 22 & 18 \\
\hline
\end{tabular}

\section{Effects of fertilizer treatments on $\mathrm{P}$ and $\mathrm{K}$ in plant biomass and soil}

There were no significant differences in $\mathrm{P}$ uptake as $\mathrm{kg} \mathrm{P} \mathrm{ha}^{-1}$ after fertilization with minNPK or MBM and CFS at any rate. Overall, utilization of fertilized $P$ tended to be best after CFS application, which resulted in the highest $P$ uptake for all rates and combinations but there were no significant differences to minNPK and MBM fertilization (Table 10). MinN fertilization resulted in fairly low $\mathrm{P}$ concentration in plant biomass, especially during the first two harvests (results are not shown). However, there were no significant differences between total P uptake as kg P ha-1 after fertilization with $\operatorname{minN}$ and $\operatorname{minNPK}$.

All MBM treatments and $300 \mathrm{~kg} \mathrm{~N}^{-1} \mathrm{CFS}$ and CFS + BWA resulted in significant effects on P-AL values in the soil in comparison to the unfertilized control treatment. All MBM treatments except for $150 \mathrm{~kg} \mathrm{~N} \mathrm{ha}^{-1} \mathrm{MBM}$ increased P-AL in the soil from low to high values according to Norwegian classifications (Krogstad et al. 2008). Also BWA tended to increase P-AL values in the soil, but significant effects on P-AL values in the soil were only found for $150 \mathrm{~kg} \mathrm{~N} \mathrm{ha}^{-1} \mathrm{MBM}$ and $300 \mathrm{~kg} \mathrm{~N} \mathrm{ha}^{-1}$ CFS, when treatments with and without BWA were compared (Table 10).

All plants were sufficiently supplied with $\mathrm{K}$ and there were no significant effects of BWA on K uptake as kg K ha ${ }^{-1}$ compared to the same treatments without BWA. The amount of plant-available $\mathrm{K}$ in the soil measured as K-AL decreased after all treatments in the course of the experiment. BWA application tended to result in larger amounts of plant-available $\mathrm{K}(\mathrm{K}-\mathrm{AL})$ in the soil compared to the same treatments without BWA, and BWA treatments of both rates (120 and $240 \mathrm{~kg} \mathrm{~K} \mathrm{ha}^{-1}$ ) were significantly different from the unfertilized control regarding K-AL contents in the soil (Table 10). 
Table 10. Uptake of total $\mathrm{P}$ and $\mathrm{K}$ in plant biomass $\left(\mathrm{kg} \mathrm{ha}^{-1}\right)$ and effects of fertilizer treatments on contents of P-AL and $\mathrm{K}-\mathrm{AL}\left[\mathrm{mg}(100 \mathrm{~g})^{-1}\right.$ soil] and $\mathrm{pH}$. See Table 1 for explanation of the abbreviations of the waste resources.

\begin{tabular}{|c|c|c|c|c|c|c|c|c|c|c|}
\hline \multirow[b]{2}{*}{ Treatment } & \multicolumn{5}{|c|}{$\begin{array}{l}\text { Application rates } \\
150 \mathrm{~kg} \mathrm{~N} \mathrm{ha}^{-1}+120 \mathrm{~kg} \mathrm{~K} \mathrm{ha}^{-1}\end{array}$} & \multicolumn{5}{|c|}{$300 \mathrm{~kg} \mathrm{~N} \mathrm{ha}^{-1}+240 \mathrm{~kg} \mathrm{~K} \mathrm{ha}^{-1}$} \\
\hline & $\begin{array}{l}\mathrm{P} \\
\mathrm{kg} \mathrm{ha} \mathrm{h}^{-1}\end{array}$ & $\begin{array}{l}\mathrm{K} \\
\mathrm{kg} \mathrm{ha} \mathrm{h}^{-1}\end{array}$ & $\begin{array}{l}\text { P-AL } \\
\text { mg } \\
(100 g)^{-1} \\
\text { soil }\end{array}$ & $\begin{array}{l}\text { K-AL } \\
\text { mg } \\
(100 g)^{-1} \\
\text { soil }\end{array}$ & $\mathrm{pH}$ & $\begin{array}{l}\mathrm{P} \\
\mathrm{kg} \mathrm{ha} \mathrm{h}^{-1}\end{array}$ & $\begin{array}{l}\mathrm{K} \\
\mathrm{kg} \mathrm{ha} \mathrm{ha}^{-1}\end{array}$ & $\begin{array}{l}\text { P-AL } \\
\text { mg } \\
(100 g)^{-1} \\
\text { soil }\end{array}$ & $\begin{array}{l}\text { K-AL } \\
\text { mg } \\
(100 g)^{-1} \\
\text { soil }\end{array}$ & $\mathrm{pH}$ \\
\hline Control & 7 & 79 & 3 & 3 & 6.7 & 7 & 79 & 3 & 3 & \\
\hline BWA & 9 & 106 & 5 & 7 & 6.8 & 9 & 114 & 5 & 8 & 6.8 \\
\hline $\operatorname{minNPK}$ & 16 & 258 & 3 & 4 & 6.5 & 23 & 412 & 4 & 4 & 6.3 \\
\hline $\min N$ & 14 & 254 & 3 & 4 & 6.8 & 18 & 317 & 3 & 4 & 6.6 \\
\hline $\min N+B W A$ & 15 & 290 & 4 & 5 & 7.0 & 19 & 350 & 4 & 6 & 6.9 \\
\hline MBM & 15 & 230 & 7 & 4 & 6.7 & 19 & 265 & 11 & 4 & 6.4 \\
\hline$M B M+B W A$ & 17 & 259 & 12 & 6 & 6.8 & 18 & 282 & 13 & 6 & 6.8 \\
\hline CFS & 18 & 227 & 4 & 4 & 6.6 & 24 & 255 & 6 & 3 & 6.4 \\
\hline CFS + BWA & 19 & 240 & 6 & 5 & 6.8 & 24 & 315 & 10 & 9 & 6.7 \\
\hline Dynea 2009 & 9 & 110 & 3 & 3 & 6.7 & 9 & 112 & 3 & 3 & 6.5 \\
\hline Dynea 2009 + BWA & 8 & 90 & 4 & 6 & 6.8 & 9 & 114 & 4 & 7 & 6.6 \\
\hline Dynea 2004 & 11 & 146 & 3 & 3 & 6.6 & 12 & 160 & 3 & 4 & 6.4 \\
\hline Dynea 2004 + BWA & 11 & 155 & 4 & 6 & 6.8 & 11 & 166 & 5 & 7 & 6.7 \\
\hline $\mathrm{MSD}^{\mathrm{a}}, p \leq 0.05$ & 6 & 85 & 3 & 3 & 0.5 & 6 & 85 & 3 & 3 & 0.5 \\
\hline
\end{tabular}

${ }^{\mathrm{a}} \mathrm{MSD}=$ minimum significant difference.

\section{Effects of fertilizer treatments on soil pH}

Overall, there were only minor effects of fertilizer treatments on soil pH as result of buffering reactions in the experimental soil, which were due to relatively high concentrations of organic material and relatively high clay content (Table 4, Table 5). BWA fertilization tended to result in higher $\mathrm{pH}$ values than the unfertilized control and all fertilizer combinations with BWA showed a tendency of higher soil pH than equivalent fertilizer treatments without BWA but effects were not significant.

\section{Discussion}

\section{Nitrogen use efficiency and mineral fertilizer equivalents of organic waste resources}

$\mathrm{N}$ uptake in aboveground biomass (NUE\%) after MBM (49-73\%) and CFS (48-59\%) fertilization and N mineralization over time were similar to results of previous studies on mineralization dynamics of MBM. Delin and Engström (2010) concluded after incubation studies with various organic waste resources under Swedish field conditions that $65 \%$ of $\mathrm{N}$ applied with MBM can be released within 30-50 days and that $\mathrm{N}$ mineralization is flattening out thereafter. Also reduced biomass production at times of the fourth harvest during the present experiment (Table 8) can be explained by decreasing $\mathrm{N}$ mineralization of MBM and CFS with time, as indicated by negligible contents of residual mineral $\mathrm{N}$ in the soil at the last day of the experiment. Mondini et al. (2008) studied mineralization dynamics of MBM under laboratory conditions for 14 days and found that $50 \%$ of $\mathrm{N}$ applied with MBM was mineralized within the course of the experiment. Consequently, scarce biomass production at the first harvest of the present experiment (Table 8) was surprising, also because ryegrass is commonly characterized by early plant development (Fustec et al. 2005). However, it was probably too deep placement of seeds that resulted in delayed germination and initial growth, rather than of a lack of mineralized $\mathrm{N}$. Total net-mineralization of $\mathrm{N}$ applied with MBM and CFS was higher than NUE\% let assume, as N uptake in root biomass was not taken into account for the calculation of NUE\%. 
Relative N replacement values of MBM and CFS (MFE\% for N uptake, Table 9) are well in accordance with studies of Delin et al. (2011), who investigated fertilization effects of MBM during two pot experiments with Italian ryegrass, and somewhat lower than equivalent values calculated based on previous studies that compared $\mathrm{N}$ uptake in grain after fertilization with MBM or CFS with mineral N fertilization (76\% in Salomonsson et al. 1995, 91\% in Jeng et al. 2004, 71-124\% in Chen et al. 2011, 80-90\% in Haraldsen et al. 2011a). Lower MFE\% for N uptake of MBM and CFS in the present study can be explained by the experimental design, which intentionally avoided denitrification and $\mathrm{N}$ leaching losses. Irrigation was adapted to the specific soil characteristics so that denitrification losses were reduced and closed plant-soil systems set up by Kick/Brauckman pots prevented nitrate from leaching to deeper soil layers. All of the studies with cereals as experimental crops referred to were conducted under field conditions or as pot experiments with an intended leaching episode. According to studies by Haraldsen et al. (2011a) and Haraldsen and Krogstad (2011) N-rich waste is less prone to nitrate leaching than mineral N fertilizer. Consequently, we may assume that immediately soluble mineral fertilizers would have come out less favourable in comparison to organic waste resources, if leaching had occurred.

MFE\% for yield tended to be higher than MFE\% for $\mathrm{N}$ uptake, indicating that MBM and CFS have the potential to result in almost equally large yield as mineral fertilizers, but in lower N concentration. If MBM or CFS is applied as fertilizer to cereals, lower $\mathrm{N}$ concentration might result in lower grain quality. This assumption is, however, not in accordance with previous studies by Salmonsson $(1994,1995)$, Fredriksson et al. $(1997,1998)$ and Chen et al. (2011) who found equally good quality parameters of cereals after fertilization with MBM as after the mineral reference treatment during field experiments.

It has to be taken into account that high MFE\% values can only be achieved, if $\mathrm{N}$ release matches with the crops' demands in time. In cereal production the time for $\mathrm{N}$ recovery is much shorter than the duration of the present experiment, where ryegrass was used as a method to study nutrient supply over time. If MBM or CFS is used as fertilizer to cereals, $\mathrm{N}$ will have to be mineralized before ear emergence, as cereal plants mainly utilize nutrients from their own vegetative reserves after this physiological stage (Spiertz and de Vos 1983). In Norway, grain is harvested 100-120 days after sowing, at a time when only $86-89 \%$ of total $\mathrm{N}$ taken up in plants after MBM and CFS fertilization was taken up by ryegrass during present experiment. MFE\% of MBM and CFS might therefore be clearly lower than presented in the present study, if applied as alternative $\mathrm{N}$ fertilizer to cereals.

\section{Relationship between fertilizer amount and $\mathrm{N}$ fertilization effect}

The effects of the highest application rates of MBM and CFS (300 kg N ha $\left.{ }^{-1}\right)$ on plant biomass were significantly different from effects of mineral fertilizer treatments of the same rate, which was puzzling because of equally good effects of the lowest rates (150 $\mathrm{kg} \mathrm{N} \mathrm{ha}^{-1}$ ) (Table 8). Decreasing effectiveness of organic fertilizers for increasing amounts is known from application of manure to agricultural land (Bioforsk 2003), and has moreover earlier been described by Boen and Haraldsen (2011) after application of increasing amounts of composted biowaste to perennial ryegrass (Lolium perenne) as well as by Trøite (2007) after studies on different organic fertilizers in a pot experiment with barley and by Kristoffersen et al. (2012) after application of increasing amounts of liquid residues from biogas production to barley. Likewise, Delin and Engström (2010) found reduced mineralization after incubation of larger amounts of various organic waste types.

A possible explanation for reduced fertilization effects of $300 \mathrm{~kg} \mathrm{~N} \mathrm{ha}^{-1} \mathrm{MBM}$ and CFS in comparison to $150 \mathrm{~kg} \mathrm{~N}$ $\mathrm{ha}^{-1}$ is a lack of oxygen when microbial activity increased with increasing amounts of organic material. Application of organic material can considerably reduce oxygen availability in the soil atmosphere with associated negative effects on plant and root growth as shown by Hossain et al. (2005) who studied the composition of soil gases after application of increasing amounts of manure. Delin and Engström (2010) suggested that reduced net-N mineralization of larger amounts of organic material could be explained by denitrification of mineralized $\mathrm{N}$ as result of anaerobic conditions due to increased microbial oxygen consumption.

Another possible explanation for decreasing fertilizer efficiency for organic waste resources at higher rates are phytotoxic effects of fatty acids, which might have accumulated when organic material was degraded under oxygen depleted conditions. Fatty acids are known to have harmful effects on germination and seedling root and shoot development (Schuman and McCalla 1976), and an accumulation after fertilization with $300 \mathrm{~kg} \mathrm{~N} \mathrm{ha}^{-1} \mathrm{MBM}$ and CFS might therefore have resulted in decreased nutrient uptake.

Oxygen deficiency and phytotoxic effects of fatty acids as result of MBM and CFS treatments might have had a particularly strong effect on biomass production during the present experiment as fertilizers were not evenly 
distributed in the soil, but concentrated at a depth of $5 \mathrm{~cm}$ in the same layer as the seeds. In similar studies on effects of organic fertilizers, the material had been mixed into the top layer to simulate even distribution by harrowing (Haraldsen et al. 2011a) or into the entire soil volume similar to incorporation by ploughing (Boen and Haraldsen 2011). However, neither oxygen supply nor the development of fatty acids was measured in the present experiment and their effects remain therefore assumptions.

\section{$\mathrm{N}$ fertilization effects of Dynea composts}

Dynea composts showed reduced $\mathrm{N}$ fertilization effects for all rates and combinations resulting in small biomass production throughout the season (Fig. 1, Table 8). This indicates that organic N in Dynea composts was rather recalcitrant. Slow N mineralization is typical for mature compost material (Amlinger et al. 2003, Bar-Tal et al. 2004, Boen and Haraldsen 2011) irrespective of its C:N ratio, as carbon in compost is of low availability and hence not well suited as source of energy to soil microorganisms. Asdal and Breland (2003) even suggested that mature compost material releases mineral $\mathrm{N}$ so slowly that the amount of inorganic $\mathrm{N}$ probably is almost equivalent to plantavailable $\mathrm{N}$ during a growing season. $\mathrm{N}$ in Dynea composts was mainly present as polymers of urea, melamine and formaldehyde. Although Dynea composts originated from industrial processes, net- $\mathrm{N}$ mineralization of these composts seemed to be at the same level as net-mineralization of mature composts based on biological organic waste materials. Based on analyses of chemical properties prior to the experiment $0.5-1 \mathrm{~kg}$ mineral $\mathrm{N}^{-1}$ and 4.7-9 kg mineral $\mathrm{N} \mathrm{ha}^{-1}$ were applied with Dynea 2009 and Dynea 2004, respectively (Table 7). Obviously these amounts were far from sufficient to supply plants with $\mathrm{N}$. Better fertilization effects of the older material can possibly be explained by larger initial amounts of mineral N in Dynea 2004 compared with Dynea 2009. The results suggest that Dynea composts can generally be applied in relatively large amounts without intensive effects on plant growth. Therefore, they are rather to be classified as soil conditioners with potentially positive effects on physical, chemical or biological soil characteristics than as fertilizers, which are defined as products with the key task of supplying plants with nutrients (Norwegian Ministry of Agriculture 2003, appendix 1).

\section{P fertilization effects of waste resources}

Even though initial contents of plant-available $\mathrm{P}$ in the soil were estimated to be low (P-AL, Table 5, Krogstad et al. 2008), the soil still supplied plants with sufficient P. Therefore, $P$ fertilization effects of waste residues did not become visible in biomass production or as $\mathrm{P}$ uptake during the present experiment. Sufficient $\mathrm{P}$ uptake despite low soil P contents can be explained by grasses being fairly tolerant to low P availability in soils in comparison to other crops (Caradus 1980) and by Italian ryegrass being adapted to P deficient conditions due to fast root development (Kemp and Blair 1994). Even plants fertilized with minN with initially low P concentration in plant tissue, achieved total yields at the same level as plants fertilized with minNPK. Delayed biomass production initiated by initial P deficiency after minN fertilization could be compensated due to the closed plant-soil system set up by Kick-Brauckmann pots, which prevented nitrate-N from leaching. Under field conditions nitrate-N would probably already have been lost by the time when plants were sufficiently supplied with P.

CFS tended to result in higher $\mathrm{P}$ uptake than MBM, even though larger total $\mathrm{P}$ amounts were applied with MBM (Table 7, Table 10). This is in agreement with studies of Haraldsen and Krogstad (2011) who found significantly higher $\mathrm{P}$ uptake by wheat after fertilization with CFS of codfish hatcheries than after MBM amendments of the same origin as in the present study. It seems, therefore, as if CFS-P is better available to plants than MBM-P, and that $\mathrm{P}$ fertilization effects of CFS are independent of $\mathrm{pH}$, whereas MBM-P apparently is more soluble in acidic than in neutral or alkaline soils (Jeng et al. 2006, Ylivainio et al. 2008).

Surprisingly, MBM fertilization resulted in an amount of soluble $\mathrm{P}$ in the plant-soil system ( $\mathrm{P}-\mathrm{AL}$ in the soil and $\mathrm{P}$ taken up by plants) that was higher than total $P$ applied with the material (Table 7, Table 10). Similar effects of MBM on plant-available P measured as P-AL were observed by Haraldsen et al. (2011a), when MBM was applied to barley. According to findings of present and previous studies, one has to question if P-AL analysis is suited as indicator for $\mathrm{P}$ fertilization effects of MBM. The present investigation indicated a need for more thorough studies on the actual P fertilization effect of MBM, and evaluations of the P-AL method as indicator for P availability in different types of organic wastes applied as P fertilizer. 


\section{$\mathrm{K}$ fertilization effect of bottom wood ash}

K fertilization effects of BWA were hidden by the soil's ability to supply plant-available $\mathrm{K}$. This is in accordance with studies of $\varnothing$ gaard et al. (2002), who found no yield response of plants on $\mathrm{K}$ fertilizers when soil $\mathrm{K}$ exceeded $8 \mathrm{mg} \mathrm{K}-\mathrm{AL}(100 \mathrm{~g})^{-1}$. The amount of plant-available $\mathrm{K}$ in the experimental soil measured as K-AL was between 8.2 and $8.7 \mathrm{mg} \mathrm{K}-\mathrm{AL}(100 \mathrm{~g})^{-1}$ and, therefore, high enough to result in luxury $\mathrm{K}$ uptake in ryegrass even after application of $\operatorname{minN}$, which supplied plants with sufficient $\mathrm{N}$ but no K. Even though $\mathrm{K}$ fertilization effects of BWA were not evident as biomass production or uptake in plant biomass, K-AL values in the soil indicated potential fertilization effects (Table 10). Also Ferreiro et al. (2011) observed an increase of K contents in the soils of mountain pastures after fertilization with wood ashes. Therefore it is likely that BWA has a long-term $\mathrm{K}$ fertilization effect when $\mathrm{K}$ contents in the soil are depleted. As BWA from Akershus Energi AS did not significantly increase soil pH (Table $10)$, it seems to be well suited for annual application to agricultural land and hence as ingredient in waste-based NPK fertilizer products.

To detect $P$ and $K$ fertilization effects of respective MBM, CFS and BWA, long-term experiments should be conducted, which guarantee sufficient supply of $\mathrm{N}$ and all other essential nutrients except the one to be studied.

\section{Conclusion}

Mineral $\mathrm{N}$ was the growth-limiting factor in the current experiment and fertilization effects of organic waste resources were therefore determined by their net-mineralization rate. $48-73 \%$ of $\mathrm{N}$ applied with meat and bone meal and composted fish sludge was taken up in aboveground biomass, resulting in mineral fertilizer equivalents of $53-81 \%$ for $\mathrm{N}$ uptake and $61-104 \%$ for yield. Decreasing mineral fertilizer equivalents for increasing fertilizer rates were most likely caused mainly by unintended concentrated application of organic waste resources. Meat and bone meal and composted fish sludge represent valuable alternative $\mathrm{N}$ fertilizers and potential ingredients in waste-based NPK fertilizer products, provided that they are included in crop rotations with $\mathrm{N}$-fixing legumes or that their $\mathrm{N}$-fertilization value is enriched with mineral $\mathrm{N}$. Dynea composts were characterized by weak $\mathrm{N}$ fertilization effects, as is typical for mature compost material, and are thus to be classified as soil conditioners rather than fertilizers. Possible $\mathrm{P}$ and $\mathrm{K}$ fertilization effects of waste resources were masked by the soil's ability to provide plant-available $\mathrm{P}$ and $\mathrm{K}$, but effects of waste resources on plant-available $\mathrm{P}$ and $\mathrm{K}$ contents in soil suggest that plant growth responses may be expected under more P- and K-deficient conditions.

\section{Acknowledgements}

The experiment, which this paper is based on, was carried out as part of CenBio WP 1.4, Bioenergy Innovation Centre (http://www.cenbio.no), which is supported by the Research Council of Norway, Norsk Protein AS and Akershus Energi AS. Moreover, the project was financially supported by Dynea ASA. We thank Hege Bergheim for her skilful technical assistance and experimental work and the anonymous reviewers who contributed with their helpful and constructive criticism on the manuscript to a significantly improved paper.

\section{References}

Amlinger, F., Götz, B., Dreher, P., Geszti, J. \& Weissteiner, C. 2003. Nitrogen in biowaste and yard waste compost: dynamics of mobilisation and availability - a review. European Journal of Soil Biology 39: 107-116.

Asdal, A. \& Breland, T.A. 2003. Compost quality related to product utilization in Norway. In: Pullammanappallil, P., McComb, A., Diaz, L.F. \& Bidlingmaier, W. (eds.). Proceedings of the 4th international conference ORBIT 2003, 30 April-2 May 2003. Weimar, Germany: ORBIT Association, p. 230-240.

Bar-Tal, A., Yermiyahu, U., Beraud, J., Keinan, M., Rosenberg, R., Zohar, D., Rosen, V. \& Fine, P. 2004. Nitrogen, phosphorus, and potassium uptake by wheat and their distribution in soil following successive, annual compost applications. Journal of Environmental Quality 33: 1855-1865.

Bioforsk 2003. Gjødslingshåndbok. Bioforsk: Norwegian Institute for Agricultural and Environmental Research. Cited 15 August 2011. Available on the internet: http://www.bioforsk.no/ikbViewer/page/prosjekt/hovedtema?p_dimension_id=19190\&p_menu_ id=19211\&p_sub_id=19191\&p_dim2=19602 (in Norwegian).

Boen, A. \& Haraldsen, T.K. 2011. Fertilizer effects of increasing loads of composts and biosolids in urban greening. Urban Forestry \& Urban Greening 10: 231-238.

Caradus, J.R. 1980. Distinguishing between grass and legume species for efficiency of phosphorus use. New Zealand Journal of Agricultural Research 23: 75-81.

Chen, L., Kivelä, J., Helenius, J. \& Kangas, A. 2011. Meat bone meal as fertiliser for barley and oat. Agricultural and Food Science 20: $235-244$. 
Cordell, D., Drangert, J.-O. \& White, S. 2009. The story of phosphorus: Global food security and food for thought. Global Environmental Change 19: 292-305.

Delin, S. 2011. Fertilizer value of nitrogen in hen and broiler manure after application to spring barley using different application timing. Soil Use and Management 27: 415-426.

Delin, S. \& Engström, L. 2010. Timing of organic fertiliser application to synchronise nitrogen supply with crop demand. Acta Agriculturae Scandinavica, Section B-Soil \& Plant Science 60: 78-88.

Delin, S., Nyberg, A. \& Stenberg, B. 2011. Short term phosphorous and nitrogen fertiliser values of different residues in pot experiments and correlations to laboratory analyses. In: Utilisation of manure and other residues as fertilizer. Proceedings of NJF seminar 443 in Falköping, Sweden, 29-30 November 2011 (NJF Report Vol. 7 No. 8). p. 12-15.

Egnér, H., Riehm, H. \& Domingo, W.R. 1960. Untersuchungen über die chemische Bodenanalyse als Grundlage für die Beurteilung des Nährstoffzustandes der Böden. Kungl. Lantbrukshögskolans Annaler 26: 199-215. (in German).

Elonen, P. 1971. Particle-size analysis of soils. Acta Agralia Fennica 122: 1-122.

EN 13654-1 2001. Soil improvers and growing media: Determination of nitrogen. Part 1: Modified Kjeldahl method. CEN, Brussels.

Ferreiro, A., Merino, A., Díaz, N. \& Pineiro, J. 2011. Improving the effectiveness of wood-ash fertilization in mixed mountain pastures. Grass and Forage Science 66: 337-350.

Frame, J. 1992. Improved grassland management. Tonbridge, Ipswich, UK: Farming Press. 351 p.

Fredriksson, H., Salomonsson, L. \& Salomonsson, A.-C. 1997. Wheat cultivated with organic fertilizers and urea: Baking performance and dough properties. Acta Agriculturae Scandinavica, Section B-Soil \& Plant Science 47: 35-42.

Fredriksson, H., Salomonsson, L. \& Salomonsson, A.-C. 1998. Effects of protein and starch characteristics on the baking properties of wheat cultivated by different strategies with organic fertilizers and urea. Acta Agriculturae Scandinavica, Section B-Soil \& Plant Science 48: 49-57.

Fustec, J., Guilleux, J., Le Corff, J. \& Maitre, J.-P. 2005. Comparison of early development of three grasses: Lolium perenne, Agrostis stolonifera and Poa pratensis. Annals of Botany 96: 269-278.

Gebauer, R. \& Eikebrokk, B. 2006. Mesophilic anaerobic treatment of sludge from salmon smolt hatching. Bioresource Technology 97: 2389-2401.

Haraldsen, T.K., Andersen, U., Krogstad, T. \& Sørheim, R. 2011a. Liquid digestate from anaerobic treatment of source separated household waste as fertilizer to barley. Waste Management and Research 29: 1271-1276.

Haraldsen, T.K., Brod, E. \& Krogstad, T. 2012. Quality requirements for wood ash as K component in recycled NPK fertilizers. Paper presented at the conference Ash Utilisation 2012: Ashes in a Sustainable Society, Stockholm, Sweden, January 25-27.

Haraldsen T.K. \& Krogstad, T. 2011. Efficiency of organic NPK fertilizers combining N-rich organic wastes and bottom wood ash. In: Utilisation of manure and other residues as fertilizer. Proceedings of NJF seminar 443 in Falköping, Sweden, 29-30 November 2011 (NJF Report Vol. 7 No. 8). p. 48-51.

Haraldsen, T.K., Pedersen, P.A. \& Grønlund, A. 2011b. Mixtures of bottom wood ash and meat and bone meals as NPK fertilizer. In: Insam, H. \& Knapp, B.A. (eds.) Recycling of Biomass Ashes. Heidelberg: Springer. p. 33-44.

Henriksen, A. \& Selmer-Olsen, A.R. 1970. Automatic methods for determining nitrate and nitrite in water and soil extracts. Analyst 95: 514-518.

Hossain, M.S., Barrington, S.F. \& Barthakur, N.N. 2005. Effect of cattle manure application on the gaseous regime of a sandy soil. Journal of Sustainable Agriculture 27: 51-70.

Jeng, A.S., Haraldsen, T.K., Grønlund, A. \& Pedersen, P.A. 2006. Meat and bone meal as nitrogen and phosphorus fertilizer to cereals and rye grass. Nutrient Cycling in Agroecosystems 76: 183-191.

Jeng, A., Haraldsen, T.K., Vagstad, N. \& Grønlund, A. 2004. Meat and bone meal as nitrogen fertilizer to cereals in Norway. Agricultural and Food Science 13: 268-275.

Jeng, A.S. \& Vagstad, N. 2009. Potential nitrogen and phosphorus leaching from soils fertilized with meat and bone meal. Acta Agriculturae Scandinavica, Section B-Soil \& Plant Science 59: 238-245.

Kemp, P.D. \& Blair, G.J. 1994. Phosphorus efficiency in pasture species. VIII. Ontogeny, growth, P acquisition and P utilization of Italian ryegrass and phalaris under P deficient and P sufficient conditions. Australian Journal of Agricultural Research 45: 669-688.

Knapp, B.A. \& Insam, H. 2011. Recycling of Biomass Ashes: Current technologies and future research needs. In: Insam, H. \& Knapp, B.A. (eds.) Recycling of biomass ashes. Heidelberg: Springer. p. 1-16.

Kristoffersen, A., Skretting, J. \& Haraldsen, T. K. 2012. Biorest av matavfall fra husholdning som gjødselkilde til korn. Bioforsk FOKUS 7: 128-133. (in Norwegian).

Krogstad, T., Øgaard, A.F. \& Kristoffersen, A.Ø. 2008. New P recommendations for grass and cereals in Norwegian agriculture. In: Phosphorus management in Nordic-Baltic agriculture: reconciling productivity and environmental protection. Proceedings of NJF seminar 401 in Uppsala, Sweden, 22-23 September 2008 (NJF Report Vol. 4 No. 4). p. 42-46.

Kuba, T., Tschöll, A., Partl, C., Meyer, K. \& Insam, H. 2008. Wood ash admixture to organic wastes improves compost and its performance. Agriculture, Ecosystems and Environment 127: 43-49.

Landbrukets analysesenter (s.a.) Veiledning til jordanalyser. Landbrukets analysesenter, Ås. (in Norwegian).

Lippestad, H. 2011. Været i Norge-klimatologisk månedsoversikt. Meteorologisk institutt. Cited 14 November 2011. Available on the internet: http://met.no/Klima/Klimastatistikk/Varet_i_Norge/2011/. (in Norwegian).

Lund, H.J., Torp, J.O., Molteberg, B. \& Krogsti, H.A. 2011. Såvarer. In: Bovim, S., Haagensen, T. (eds.) Håndbok i plantekultur 2011. Oslo: Norgesfôr AS, p. 9-63. (in Norwegian). 
Mattilsynet 2009. Veileder B: Utfyllende informasjon om økologisk landbruksproduksjon: Veileder til forskrift om økologisk produksjon og merking av landbruksprodukter og næringsmidler, av 4. oktober $2005 \mathrm{nr}$. 1103. Oslo: Mattilsynet: Statens tilsyn for planter, fisk, dyr og næringsmidler. Updated 28 May 2009. Cited 8 July 2011. Available on the internet: http://www.debio.no/_upl/ veileder_b.pdf. (in Norwegian).

Mondini, C., Cayuela, M. L., Sinicco, T., Sánchez-Monedero, M. A., Bertolone, E., \& Bardi, L. 2008. Soil application of meat and bone meal. Short-term effects on mineralization dynamics and soil biochemical and microbiological properties. Soil Biology and Biochemistry 40: 462-474.

Mozaffari, M., Russelle, M.P., Rosen, C.J. \& Nater, E.A. 2002. Nutrient supply and neutralizing value of alfalfa stem gasification ash. Soil Science Society of America Journal 66: 171-178.

NGU 2011. Berggrunnsgeologidatabasen. Norges geologiske undersøkelse. Updated: 19 July 2012. Cited 15 August 2011. Available on the internet: http://www.ngu.no/kart/bg250/. (in Norwegian).

Norwegian Ministry of Agriculture 2003. Forskrift om gjødselvarer mv. av organisk opphav. Updated 7 April 2006. Cited 8 July 2011. Available on the internet: http://www.lovdata.no/for/sf/ld/xd-20030704-0951.html\#27. (in Norwegian).

Norwegian Ministry of Fisheries and Coastal 2008. Forskrift om drift av akvakulturanlegg. Updated 22 November 2010. Cited 13 September 2011. Available on the internet: http://www.lovdata.no/for/sf/fi/xi-20080617-0822.html. (in Norwegian).

NS-EN 13037 2000. Soil improvers and growing media: Determination of pH. CEN, Brussels.

NS-EN 13654-2 2001. Soil improvers and growing media: Determination of nitrogen. Part 2: Dumas method. CEN, Brussels.

NS-EN ISO 11885 2009. Water quality: Determination of selected elements by inductively coupled plasma optical emission spectrometry (ICP-OES). CEN, Brussels.

NS 4720 1979. Water analysis: Determination of pH. CEN, Brussels.

NS 4770 1994. Water analysis: Determination of metals by atomic absorption spectrophotometry, atomization in flame. General principles and guidelines. CEN, Brussels.

$\emptyset$ gaard, A.F., Krogstad, T., Lunnan, T. 2002. Ability of some Norwegian soils to supply grass with potassium (K)-soil analyses as predictors of K supply from soil. Soil Use and Management 18: 412-420.

Paulsrud, B., Wien, A. \& Nedland, K.T. 1997. Miljøgifter i norsk kompost og husdyrgjødsel. Oslo: Statens forurensningstilsyn. SFTreport 97.26 p. (in Norwegian).

Pradhan, S.K., Holopainen, J.K., Weisell, J. \& Heinonen-Tanski, H. 2010. Human urine and wood ash as plant nutrients for red beet (Beta vulgaris) cultivation: Impacts on yield quality. Journal of Agricultural and Food Chemistry 58: 2034-2039.

Pratt, P.F. 1965. Potassium. In: Black, C.A. (ed.) Methods of soil analysis, part 2. Chemical and microbiological properties. Madison: American Society for Agronomy, p. 1023-1031.

Salomonsson, L., Jonsson, A., Salomonsson, A.-C. \& Nilsson, G. 1994. Effects of organic fertilizers and urea when applied to spring wheat. Acta Agriculturae Scandinavica, Section B-Soil \& Plant Science 44: 170-178.

Salomonsson, L., Salomonsson, A.-C., Olofsson, S. \& Jonsson, A. 1995. Effect of organic fertilizers and urea when applied to winter wheat. Acta Agriculturae Scandinavica, Section B-Soil \& Plant Science 45: 171-180.

SAS Institute Inc. 1989. SAS/STAT User's Guide, Version 6, vol 1. 4th edn. Cary, NC, USA: SAS Institute Inc.

Schiemenz, K., Kern, J., Paulsen, H.-M., Bachmann, S. \& Eichler-Löbermann, B. 2011. Phosphorus fertilizing effects of biomass ashes. In: Insam, H., Knapp, B.A. (eds.) Recycling of Biomass Ashes. Heidelberg: Springer. p. 17-31.

Schuman, G. E, \& McCalla, T. M. 1976. Effect of short-chain fatty acids extracted from beef cattle manure on germination and seedling development. Applied and Environmental Microbiology 31: 655-660.

Selmer-Olsen, A.R. 1971. Determination of ammonium in soil extracts by an automated indophenol method. Analyst 96: 565-568.

Spiertz, J. H. J., \& de Vos, N. M. 1983. Agronomical and physiological aspects of the role of nitrogen in yield formation of cereals. Plant and Soil 75: 379-391.

SSB 2011. Tabell 350: Sal av handelsgjødsel og kraftfôr. Tonn. Statistisk sentralbyrå. Updated 20 October 2011. Cited 16 February 2012. Available on the internet: http://www.ssb.no/aarbok/tab/tab-350.html. (in Norwegian).

Teuber, N., Alfaro, M.A., Salazar, F.J. \& Bustos, C. 2005. Sea salmon sludge as fertilizer: effects on a volcanic soil and annual ryegrass yield and quality. Soil Use and Management 21: 432-434.

Trøite, T. 2007. Kjøttbeinmjøl som gjødsel i økologisk korndyrking. Master thesis. Ås, Norway: Norwegian University of Life Sciences. 47 p. (in Norwegian).

Uhlig, C. \& Haugland, E. 2007. Gjødsel kvalitet av fiskeslam og fiskeensilasje fra landbasert røyeoppdrett for dyrking av timotei (Phleum pratense). Bioforsk FOKUS 2: 53-56. (in Norwegian).

van Kauwenbergh, S. J. 2010. World phosphate rock reserves and resources. Muscle Shoals, Alabama, USA: International Fertilizer Development Center. 48 p.

Ylivainio, K., Uusitalo, R. \& Turtola, E. 2008. Meat bone meal and fox manure as P source for ryegrass (Lolium multiflorum) grown on a limed soil. Nutrient Cycling in Agroecosystems 81: 267-278. 